\title{
Neutronics and Thermal Design Calculations of a Small Single-Purpose Desalination System for the Production of 2.6 MGPD of Fresh Water
}

\author{
Dheya Shuja'a Al-Othmany \\ Associate Prof. of Nuclear Engineering, Faculty of Engineering, \\ King Abdulaziz University, Jeddah, Saudi Arabia
}

\begin{abstract}
This research is a based on conceptual design of single purpose desalination system by utilizing the Nuclear Energy so that the Sea water can be utilized for the use of industrial and potable purpose. The power required for the desalination of 2.6 MGPD was $40 \mathrm{MWth}$. The fuel used in the nuclear reactor is Uranium Dioxide $\left(\mathrm{UO}_{2}\right)$ with $3 \%$ enrichment. The coolant used is light water $\left(\mathrm{H}_{2} \mathrm{O}\right)$ which is also used in the intermediate looping. To slow the fast neutrons to thermal energy, the moderator used is also the light water. Multi-Effect Desalination (MED) process is considered as a process of desalination after analyzing various quality and economic benefits. The fuel was designed and arranged in the core using 4 assemblies with each assembly having a matrix of $15 \times 15$ fuel rods. The thermal designed of this study is based on the standards as mentioned by the International Atomic Energy Agency (IAEA). The core neutronics and thermal parameters resulted in $3 \%$ enriched fuel of $\mathrm{UO}_{2}$. On the basis of numerical analysis using the similar conditions we have selected the parameters like He layer thickness, cladding thickness of Zircalloy material, length of fuel rods and coolant bulk temperature. By executing the necessary design calculations, the nuclear reactor design was finalized which is meant only for heating purpose.
\end{abstract}

Keywords: desalination system, nuclear design, thermal design, nuclear fuel, MED

DOI: $10.7176 / \mathrm{JETP} / 9-4-01$

Publication date: April $30^{\text {th }} 2019$

\section{INTRODUCTION}

Fresh water is emerging as the most critical resource issue facing humanity. While the supply of fresh water is limited, both the world's population and demand for the resource continues to expand rapidly. The world's rapid population growth over the last century has been a major factor in increasing global water usage. Caught between (a) finite and increasingly polluted water supplies, and (b) rapidly rising demand from population growth and development, many developing countries face difficult and uneasy choices.

Population and water resources are closely connected. At some point, however, this increased demand becomes overuse, leading to depletion and pollution of surface and groundwater supplies that can cause chronic water shortages. In less than 30 years, 50 countries could face serious water shortages, affecting more than 3.3 billion people $-40 \%$ of the projected global population $[1,2]$.

Saline Water can be turned into fresh water via process named as "Desalination" which is also the basic theme of this project. It is not a modern science. Desalination/distillation is one of mankind's earliest forms of water treatment, and it is still a popular treatment solution throughout the world today. The basic process of desalination is that Saline water is taken and is provided heat which evaporates the water, this water then comes in contact with the cooled air where it re-condenses to form dew or rain and hence water is now free from salt.

The process of Desalination can be employed on an Industrial and Commercial level. There are number of ways to provide the heat for the desalination of saline water namely by utilizing the Sun energy, by the combustion of Natural gas and then utilizes its heat, by the combustion of Coal. One the most economic method for this purpose is the "Nuclear Desalination" method which is also the title of this project. The most important users of this method are in the Middle East, (mainly Saudi Arabia, Kuwait, the United Arab Emirates, Qatar and Bahrain), which uses about $70 \%$ of worldwide capacity; and in North Africa (mainly Libya and Algeria), which uses about $6 \%$ of worldwide capacity [3].

The following sheets will represent a study to design a Nuclear Desalination System for the production of 2.6 MGPD of fresh water which is the objective of the project i.e. design of a single purpose nuclear desalination system for production of 2.6MGPD of fresh water. The thermal power required for the production of this amount of water in $40 \mathrm{MW}$ by using nuclear reactor and nuclear fuel.

Within the last decade or more, there has been a growing interest in using nuclear energy for the desalination purpose. Some feasibility studies conducted by the IAEA have proven the viability of using nuclear energy as a source to desalination from an economic and technical perspective. The nuclear desalination consists of 2 parts; nuclear and desalination unit. Sometimes the desalination unit is accompanied with unit of electrical generation so that a fraction of the thermal energy generated from the reactor is utilized to generate electrical power. Nuclear power shares $16 \%$ of the electricity in the world within 30 countries. Within last 5 decades, about 10,000 reactor 
-years of operation have been experienced. Recently, the idea of merging desalinating seawater with producing electrical power by nuclear option has been thought of to overcome the water shortage. Globally, over 175 reactoryears of operation experience on nuclear desalination have been accumulated. IAEA supports progresses on nuclear desalination programs to investigate its economic and technical viability.

The experience and developments in nuclear desalination is summarized and shown in Table 1 with type of the reactor, its location, its status and the desalination method.

Table 1: Nuclear reactor types based on desalination processes

PWR: pressurized water reactor; BWR: boiling water reactor; NHR: nuclear heat producing reactor; LMFR: liquid metal fast reactor; HTR: high temperature reactor; HWR: heavy water reactor; MED: multi-effect distillation; MSF: multi stage flash distillation; RO: reverse osmosis.

\begin{tabular}{|c|c|c|c|}
\hline Type & $\begin{array}{l}\text { Desalination } \\
\text { method }\end{array}$ & Status & Location \\
\hline \multirow{3}{*}{ PWRs } & MED & Under design & $\begin{array}{l}\text { Rep. of } \\
\text { Korea,Argentina, etc. }\end{array}$ \\
\hline & MED, RO & Under consideration (floating unit) & Russian Federation \\
\hline & MED, MSF, RO & $\begin{array}{l}\text { In service with operating experience of } \\
\text { over } 125 \text { reactor-years. }\end{array}$ & $\begin{array}{l}\text { Japan (Ohi, Takahama, } \\
\text { Ikata, Genkai) }\end{array}$ \\
\hline BWR & MSF & $\begin{array}{l}\text { Never in service following testing in } \\
1980 \text { s, due to alternative freshwater } \\
\text { sources; dismantled in } 1999 \text {. }\end{array}$ & $\begin{array}{l}\text { Japan } \quad \text { (Kashiwazaki- } \\
\text { Kariva) }\end{array}$ \\
\hline NHR-200 & MED & Under design & China \\
\hline LMFR & MED, MSF & In service till 1999 & Kazakhstan (Aktau) \\
\hline HTRs & MED, RO & Under development and design & $\begin{array}{l}\text { France, The Netherlands, } \\
\text { South Africa, USA }\end{array}$ \\
\hline \multirow{2}{*}{ HWR } & MED & Under construction & Pakistan (KANUPP) \\
\hline & $\mathrm{MSF} / \mathrm{RO}$ & Under commissioning & India (Kalpakkam) \\
\hline
\end{tabular}

Nuclear desalination has historical experience, in 1999 Kazakhstan and Japan has exceeded 100 reactor-years. It has been proven in safety concern that no incidents had been made associated with nuclear desalination. Many activities are in progress in Member States to validate economic and technical viability of nuclear desalination. Technical Co-operation and Co-ordinated Research Projects facilitates used by IAEA for technical assistance that includes connection of a desalination system and experimental work to an existing nuclear power plant [4]. 
Table 2: Techno-economic feasibility studies

Argentina Has a small reactor (CAREM) that could be used for desalination. Initiative on safety features of nuclear desalination statements applied implementation and improvements and parts developments around the world.

China Arranged with many theoretical designs of nuclear desalination using NHR type heating reactor for coastal Chinese cities. A authorizing the thermal hydraulics factors of MED (multi effect distillation) process has been set up a test system by INET (Institute of Nuclear Energy Technology, Tsinghua University, Beijing).

\begin{tabular}{|c|c|}
\hline Egypt & $\begin{array}{l}\text { Has a nuclear co-generation plant (water\& electricity) a completed feasibility study at El-Dabaa. } \\
\text { It has a pre-heat RO test facility at El-Dabaa nearing to be constructed. }\end{array}$ \\
\hline France & $\begin{array}{l}\text { Lately entered into a number of international cooperation: one with Libya aimed at a technical } \\
\text { and economic feasibility of the Libyan site-specific adaptation of the Libyan experimental } \\
\text { reactor at Tajura into a nuclear desalination demonstration plant study using both processes RO } \\
\text { and MED in hybrid combination. The other is in cooperation with Morocco (project AMANE) } \\
\text { to study the technical and economic feasibility of the sites Agadir and Laayoun. Under the } \\
\text { bilateral cooperation signed between India and France, as it was agreed that the two partners will } \\
\text { cooperate on the development of advanced mathematical models, which will then be validated } \\
\text { in the Indian nuclear facilities (and CIRUS Experimental Reactor station Kalpakkam, with } \\
\text { hybrid MSF-RO systems ). }\end{array}$ \\
\hline Israel & $\begin{array}{l}\text { Continue to provide technical and economic information on low-cost water desalination } \\
\text { technologies and their application to desalination plants on a large scale on a regular basis. }\end{array}$ \\
\hline Japan & $\begin{array}{l}\text { Continue with the operation of its nuclear facilities for the desalination of shared water at the } \\
\text { site within many nuclear power plants. }\end{array}$ \\
\hline $\begin{array}{l}\text { Republic of } \\
\text { Korea }\end{array}$ & $\begin{array}{l}\text { Initiating with its SMART (System-integrated Modular Advanced Reactor) concept. The project } \\
\text { aims to produce } 40000 \mathrm{~m}^{3} / \text { day of potable water. }\end{array}$ \\
\hline Morocco & $\begin{array}{l}\text { Continue to develop legislative and regulatory nuclear appropriate legal and institutional } \\
\text { framework process while staying abreast of technical developments in the field of public and } \\
\text { nuclear desalination. }\end{array}$ \\
\hline Tunisia & $\begin{array}{l}\text { Completed its technical and economic feasibility study, in collaboration with France and the site } \\
\text { la-Skhira in the southeastern part of the country. The final report, submitted in March } 2005 \text { a } \\
\text { very positive by the Tunisian authorities, who already announced their willingness to go for the } \\
\text { option of nuclear desalination. }\end{array}$ \\
\hline USA & $\begin{array}{l}\text { Will be included in the roadmap initiative for the fourth generation of its detailed discussion of } \\
\text { the possible products of nuclear energy in recognition of the important role that could be the } \\
\text { future of nuclear energy systems play in the production of fresh water. }\end{array}$ \\
\hline
\end{tabular}

\section{NUCLEAR DESIGN CLACULATIONS OF DESALINATION SYSTEM}

Power generation in a reactor core is limited to thermal characteristics rather than nuclear properties as neutronflux has no limit i-e the work is needed only to remove heat generated.

Rate of heat generation is directly related to rate of reaction, and rate of reaction is given as:

And thus rate of heat generation is given as,

$$
\mathrm{R}=\in \varphi
$$

Where

$$
\begin{aligned}
& \text { q"' }=\mathrm{GR} \quad ; \in=\sigma \mathrm{N} \\
& \mathrm{q}^{\prime \prime \prime}=\mathrm{G}_{\mathrm{f}} \mathrm{N}_{\mathrm{ff}} \sigma_{\mathrm{f}} \varphi
\end{aligned}
$$

q'" = volumetric source strength

$\mathrm{G}=$ energy per reaction

$\mathrm{N}=$ fissionable fuel density

$\sigma_{\mathrm{f}}=$ microscopic cross section

$\varnothing=$ neutron flux

The volumetric thermal source strength at any one position in a core is directly proportional to the neutron flux at that position. A fuel element is usually situated vertically in a heterogeneous core such that its length is equal to height of the core. The fuel cross section area is so small compare to that in the core that the radial variation in the flux is negligible. The axial variation in flux is taken into account and the neutron flux drops to zero at some extrapolated height $\mathrm{He}$, i.e. $\varnothing=0$ at $\mathrm{z}= \pm \mathrm{He} / 2$. If the variation of neutron flux in axial direction is pure cosine function of $z$ the maximum value of $\varnothing$ and q" " occurs at the center. Other fuel elements closer to the center of the core normally have higher values of neutron flux and $\mathrm{q}_{\mathrm{c}}$ ", . It should be indicated here that when the reactivity varied with $z$, because of a large axial temperature rise in a water-moderated core or because of change in phase, 
such as in the boiling water reactor or in fuel enrichment because of uneven burn up, or because of partially inserted control rods, the axial flux may deviate appreciably from the cosine function. In such cases some other relationship between q", and z should be used [5].

Using the Heat Conduction Equation

$$
\begin{gathered}
\left(U^{\phi+\Delta \phi}-U^{\phi}\right)=(q x+q y+q z) \Delta \phi-(q x+\Delta x+q y+\Delta y+q z+\Delta z) \Delta \phi-(q x+\Delta x+q y+\Delta y \\
+q z+\Delta z) \Delta \phi \\
-(q x+\Delta x+q y+\Delta y+q z+\Delta z) \Delta \phi+\left(\Delta x \Delta y \Delta z q^{\prime \prime \prime}\right) \Delta \phi
\end{gathered}
$$

After simplifying using assumptions we get;

In cylindrical or polar coordinates:

$$
\frac{\delta^{2} t}{\delta X^{2}}+\frac{\delta^{2} t}{\delta Y^{2}}+\frac{\delta^{2} t}{\delta Z^{2}}+\frac{q^{\prime \prime \prime}}{k}=\left(\frac{1}{\alpha}\right) \cdot\left(\frac{\delta t}{\delta \phi}\right)
$$

$$
\nabla^{2} t=\frac{\delta^{2} t}{\delta r^{2}}+\left(\frac{1}{r}\right) \cdot\left(\frac{\delta t}{\delta r}\right)+\left(\frac{1}{r^{2}}\right) \cdot\left(\frac{\delta^{2} t}{\delta r^{2}}\right)+\frac{\delta^{2} t}{\delta Z^{2}}
$$

In one dimensional case:

In cylindrical or polar coordinates:

$$
\nabla^{2} t+\frac{q^{\prime \prime \prime}}{k}=\left(\frac{1}{\alpha}\right) \cdot\left(\frac{\delta t}{\delta \phi}\right)
$$

$$
\nabla^{2} t=\frac{d^{2} t}{d r^{2}}+\left(\frac{2}{r}\right)\left(\frac{d t}{d r}\right)
$$

The amount of reactor power generation in a given reactor is limited by thermal rather than by nuclear considerations. The reactor core must be operated at such a power level that with the best available heat-removal system, the temperatures of the fuel and cladding anywhere in the core must not exceed safe limits.

Reactor cores are usually limited by those parameters that cause the temperatures to exceed safe limits. In liquid-cooled reactors theses may be the burnout heat flux, which affects the cladding surface. In gas-cooled reactors the relatively low heat-transfer coefficients would pose limitations on the fuel centerline or cladding temperatures. Before starting this calculation it should be noted that we have been defined our reactor power to be of $40 \mathrm{MW}$ and fuel enrichment to be of $3 \%$. Further we shall be using $15 \times 15$ matrixes. We have set fuel cycle of 2.5 years i-e after this period the fuel burn up will occur [6,7].

As we know only element $\mathrm{U}_{235}$ is responsible for fission and oxygen in $\mathrm{UO}_{2}$ will not take part in fission i-e our total thermal power shall be obtained from uranium $\mathrm{U}_{235}$ element.[4]

Since, 1 Watt $=3.12 \times 10^{10}$ fissions $/ \mathrm{sec}$

\section{$40 \mathrm{MW}=1.248 \times 10^{18}$ fissions $/ \mathrm{sec}$}

For fuel cycle time of 2.5 years we require

Total No of fissions $=9.828 \times 10^{25}$

For each fission reaction, we require $\mathrm{U}^{235}$ atom (Ignoring fast fission in $\mathrm{U}^{238}$ )

Total no of $U^{235}$ atoms required $=9.828 \times 10^{25}$

Since our fuel is $3 \%$ enriched

$$
\text { Total no of Uranium atoms }=\frac{9.828 \times 1025}{0.03}
$$

Total no of Uranium atoms $=3.276 \times 10^{27}$

Each $\mathrm{UO}_{2}$ molecule contains 1 Uranium atom

Total no of $\mathrm{UO}_{2}$ molecules $=3.276 \times 10^{27}$

The purpose of moderator is to convert all the fast neutrons to thermal neutrons. Thus there is a relation between number of fissions and number of hydrogen atom,

Number of Hydrogen Atoms $=524 \times 9.828 \times 10^{25}$

Number of Hydrogen Atoms $=5.14 \times 10^{28}$ atoms

Since each oxygen atom is combined with 2 hydrogen atom therefore the number of $\mathrm{H}_{2} \mathrm{O}$ molecules would be [4],

\section{Number of $\mathrm{H}_{2} \mathrm{O}$ Molecules $=\mathbf{2 . 5 7} \times \mathbf{1 0}^{28}$ molecules}

The basic principle for finding fuel and moderator volume is to know the atom density for each. Dividing molecules by atom density gives volume. We will utilize the fuel volume in recognizing the rod volume and utilize the moderator volume to recognize pitch of the cell.

Volume of Fuel is determined as 


$$
\begin{aligned}
& N_{U O 2}\left(\frac{\text { molecules }}{\mathrm{cm}^{3}}\right) \\
& =6.02 \times 10^{23} \frac{\text { molecule }}{\text { mole }} \times \frac{10.97 \frac{\mathrm{g}}{\mathrm{cm}^{3}}}{238 \frac{\mathrm{g}}{\text { mole }} \times 0.97+235 \frac{\mathrm{g}}{\mathrm{mole}} \times 0.03+16 \frac{\mathrm{g}}{\mathrm{mole}} \times 2} N_{U 02}\left(\frac{\text { molecules }}{\mathrm{cm}^{3}}\right) \\
& \mathrm{N}_{\text {uo2 }}\left(\frac{\text { molecules }}{\mathrm{cm}^{3}}\right)=2.446 \times 10^{22}
\end{aligned}
$$

Volume of $\mathrm{UO}_{2}=3.27 \times 10^{27} / 2.44 \times 10^{22}$

$$
=133932.95 \mathrm{~cm}^{3}
$$

Similarly, amount of fuel required can be calculated as,

$$
\begin{aligned}
& \text { Mass of } \mathrm{UO}_{2}=\text { density x volume } \\
& \text { Mass of } \mathrm{UO}_{2}=10.97 \times 133932.95 \\
& \text { Mass of } \mathbf{U O}_{2}=\mathbf{1 4 6 9 2 4 4 . 4 6 2} \mathbf{g m} \\
& \text { Mass of } \mathbf{U O}_{2}=\mathbf{1 4 6 9 . 2 4 4 4} \mathbf{~ K g}
\end{aligned}
$$

Volume of Moderator is determined as

$$
\begin{aligned}
& \qquad N_{H 2 O}=6.02 \times \frac{10^{23} \text { molecules }}{\text { mole }} \times \frac{1 \frac{\mathrm{g}}{\mathrm{cm}^{3}}}{(2 \times 1+16) \frac{\mathrm{g}}{\mathrm{mole}}} \\
& =3.34 \times 10^{22} \text { molecules } / \mathrm{cm}^{3}
\end{aligned}
$$

Total moderator volume needed is $\mathrm{V}_{\mathrm{H} 2 \mathrm{O}}$ :

$$
\begin{aligned}
& V_{H 2 O}=\frac{H 2 O \text { molecules }}{N_{H 2 O}} \\
& V_{H 2 O}=\frac{2.57 \times 1028}{3.34 \times 1022} \\
& =770938.922 \mathrm{~cm}^{3} \\
& V_{H 2 O}=0.77 \mathrm{~m}^{3}
\end{aligned}
$$

A unit cell is an arrangement of four quarters of four rods separated by the pitch distance. Therefore, we have to know that each cell contains one rod (4 quarters). Because each unit cell does represent one rod therefore the number of unit cells will be equal to the number of rods. Coolant will flow in the area between the four quarters. Now let us start the flow of calculations:

Number of unit cells (channels) = number of fuel rods

Each quarter from each rod will represent one rod that belongs to the channel

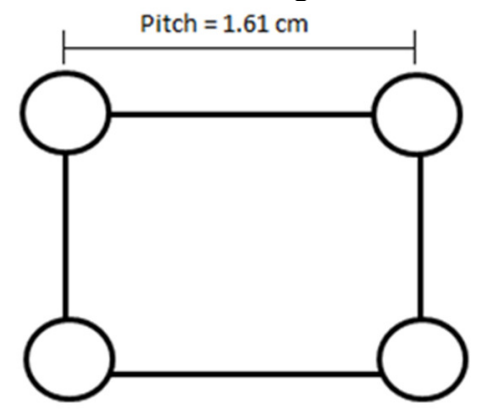

Figure1: Unit cell arrangement

Since we have $15 \times 15$ assembly i-e 225 rods per assembly,

NO. of assemblies $=4$

Volume of fuel per rod per assembly $=133932.5 / 225 \times 4$

$$
=148.814 \mathrm{~cm}^{3}
$$

No. of assemblies is obtained from iterations, since no. of assembly $j$ assembly. Both of the parameters are calculated in next sections. Now, Height of $\operatorname{rod}=4 \mathrm{~m}$

$\mathrm{V}_{\mathrm{rod}}=\pi / 4 \mathrm{D}^{2} \times \mathrm{H}$

$148.814=\pi / 4 \mathrm{D}^{2} \mathrm{x} 400$

Diameter of pellet $=0.688 \mathrm{~cm}$

Using numerical analysis, following data has been found compatible with the chosen configuration of fuel rod. 
Since we are using uranium dioxide as fuel thus we need to use helium layer between fuel and cladding in rod.

1. Thickness of He layer $=4.128 \times 10^{-3} \mathrm{~cm}=1.35 \times 10^{-4} \mathrm{ft}$

2. Thickness of Zircalloy (cladding) $=0.041 \mathrm{~cm}=1.345 \times 10^{-3} \mathrm{ft}$

\section{Therefore:}

Total outer radius of $\mathbf{r o d}=0.688 / 2+0.041+4.128^{-3}=\mathbf{0 . 3 8 9} \mathbf{~ c m}$

Now, we need to find pitch length which can be calculated as follows:

Volume of Moderator per Channel $=\mathrm{P}^{2} \times \mathrm{H}-\frac{\pi x D^{2} * H}{4}$

$$
\begin{aligned}
& \frac{0.77}{4 \times 225 \times 4 \mathrm{~m}}=\mathrm{P}^{2}-\frac{3.142}{4}\left(2 \times 0.389 \times 10^{-2}\right)^{2} \\
& \mathrm{P}=0.0161 \mathrm{~m} \\
& \mathbf{P}=\mathbf{1 . 6 1} \mathrm{cm}
\end{aligned}
$$

Neutron flux at the core center can be evaluated as,

Using heat generation equation

Where;

$$
q=\int_{V} \operatorname{Er} \Sigma_{f} \phi(r, \theta, \mathrm{z}) d V
$$

$$
\begin{aligned}
& \mathrm{Er}=\text { fission energy }=180 \mathrm{MeV} \\
& \mathrm{E}_{\mathrm{r}}=180(\mathrm{MeV}) \times 1.6 \times 10^{-13} \frac{\mathrm{J}}{\mathrm{MeV}}
\end{aligned}
$$

$\Sigma_{\mathrm{f}}=$ macroscopic cross section fission $(\mathrm{cm}-1)$.

$\sum_{\mathrm{f}}=\mathrm{N}_{\mathrm{f}} * \sigma_{\mathrm{f}}$

$$
\mathrm{N}_{\mathrm{f}}=\mathrm{A}_{\mathrm{v}} \frac{\rho . r}{A w}
$$

Where;

$\mathrm{N}_{\mathrm{f}}=$ fission atom density (nuclei/cm3).

$\rho=$ density for Uranium $=19.1 \mathrm{~g} / \mathrm{cm} 3$.

$\mathrm{r}=$ enrichment $=0.03$

Av $=$ Avogadro's number $=0.6022 \times 1024$ atoms $/$ mole.

$\mathrm{Aw}=$ atomic weight $=235$.

$\mathrm{N}_{\mathrm{f}}=6.02 \times 10^{23} \frac{(19.1)(0.03)}{235}$

$\mathrm{N}_{\mathrm{f}}=1.46 \times 10^{21 \text { atoms }} / \mathrm{cm} 3$

For $\mathrm{U}^{235}$;

$\sigma_{\mathrm{f}}=587$ barn $=587 \times 10^{-24} \mathrm{~cm}^{-3}$

$\varnothing=$ space flux $[\mathrm{n}$ 's/(cm2 sec $)]$.

$\varnothing(\mathrm{r}, \theta, \mathrm{z})=\emptyset_{\mathrm{co}} \mathrm{J}_{\mathrm{o}}\left(\frac{2.405 r}{R}\right) \cos \left(\frac{\pi \mathrm{z}}{H}\right)$

Therefore;

$\mathrm{q}=\left(180 \times 1.6 \times 10^{-13}\right)\left(1.46 \times 10^{21} \times 587 \times 10^{-24}\right) \int_{-H / 2}^{H / 2} \int_{0}^{2 \pi} \int_{0}^{R}\left(\varnothing_{\mathrm{co}} \mathrm{J}_{\mathrm{o}}\left(\frac{2.405 r}{R}\right) \cos \left(\frac{\pi z}{H}\right) \mathrm{drd} \theta \mathrm{dz}\right.$

$\mathrm{q}=2.46 \times 10^{-11} \int_{-H / 2}^{H / 2} \int_{0}^{2 \pi} \int_{0}^{R}\left(\varnothing_{\operatorname{co}} \mathrm{J}_{\mathrm{o}}\left(\frac{2.405 r}{R}\right) \cos \left(\frac{\pi z}{H}\right) \mathrm{drd} \theta \mathrm{dz}\right.$

$\mathrm{q}=2.46 \times 10^{-11} \emptyset_{\mathrm{co}}\left\{\int_{-\frac{H}{2}}^{\frac{H}{2}} \cos \left(\frac{\pi z}{H}\right) \mathrm{dz}\right\}\left\{\int_{0}^{2 \pi} d \theta\right\}\left\{\int_{0}^{R} J\left(\frac{2.405}{R}\right) r d r\right\}$

$\mathrm{q}=2.46 \times 10^{-11} \emptyset_{\mathrm{co}}\left\{\left|\frac{-H}{2 \pi} \sin \frac{\pi z}{H}\right|_{-H / 2}^{H / 2}\right\}\left\{\left\{|\theta|_{0}^{2 \pi}\right\}\left\{\left\{\left|\frac{R}{2.405} \cdot r J\left(\frac{2.405 r}{R}\right)\right|_{o}^{R}\right\}\right.\right.$

$\mathrm{q}=2.46 \times 10^{-11} \emptyset_{\mathrm{co}}\left\{\frac{H}{\pi} \sin \left\{\frac{\pi}{H}\left(\frac{H}{2}\right)\right\}-\sin \left\{\frac{\pi}{H}\left(\frac{-H}{2}\right)\right\}\right\}\{2 \pi\}\left\{\frac{R}{2.405} \cdot r J\left(\frac{2.405 r}{R}\right)\right\}$

$\mathrm{q}=2.46 \times 10^{-11} \emptyset_{\mathrm{co}}\left\{\frac{H}{\pi} \cdot 2 \sin \left(\frac{\pi}{2}\right)\right\}\{2 \pi\}\left\{\frac{R}{2.405} \cdot R J(2.405)\right\}$

$\mathrm{q}=2.46 \times 10^{-11} \emptyset \operatorname{co}\left\{(2 \pi)\left(\frac{H}{\pi}\right)\left(\frac{R}{2.405}\right)\right\}\left\{2 \sin \frac{\pi}{2} \cdot R J(2.405)\right\}$

From table;

$\mathrm{J}(2.405)=0.5202$

$q=2.46 \times 10^{-11}\left\{2 \pi \cdot \frac{1}{\pi} \cdot \frac{1}{2.405} \cdot(2)(1)(0.5202)\right\} \varnothing_{c o} R^{2} H$

$q=2.12 \times 10^{-11} \emptyset_{\text {co }} R^{2} H$ 
Since,

$\mathrm{q}=40 \times 10^{6} \mathrm{~W}$

$\mathrm{R}=77.23 / 2 \mathrm{~cm}$

$\mathrm{H}=4 \mathrm{~m}=400 \mathrm{~cm}$

Therefore,

$\emptyset_{\mathrm{co}}=3.16 \times 10^{12} \frac{\text { nuclei }}{\mathrm{cm}^{\wedge} 2 . \mathrm{sec}}$

\section{THERMAL AND HYDRAULIC DESIGN OF NUCLEAR REACTOR}

These calculations are mainly based on coolant flow in channels. The heat obtained from fuel must be transferred to the pressurized coolant, this heat transferred is mainly concerned with the desalination capability as in intermediate looping this amount of heat will be required to produce steam that runs our desalination system. Coolant flow in channel must be accurately calculated so that the fuel has to be arranged in a way that guarantees achieving our purpose [8].

Since coolant will flow through the channels, extracting heat from the fuels therefore care should be taken in setting the pressure as it would be hazardous if the coolant boils so for this reason we have utilized the standard parameters of PWR by setting pressure of 16MPa and bulk fluid temperature of about 322 degree Celsius.

$\begin{array}{rll}\text { Primary Coolant Flow } & = & \frac{q}{h 2-h 1} \\ & = & \frac{40 \times 103}{93.401} \\ \text { Primary Coolant Flow } & = & \mathbf{4 2 8 . 2 6} \mathbf{~ k g} / \mathrm{s}\end{array}$

Using iterations and thermal analysis, we have found that there would be 4 assemblies in the system each with 225 fuel rods. The fuel rod content is a disk of fuel pellet surrounded by cladding material with small gap between them filled with Helium gas.

Fuel Pellet $\quad 3 \%$ enriched $\mathrm{UO}_{2}, 0.688 \mathrm{~cm}$ diameter and $1.5 \mathrm{~cm}$ long.

Cladding Zircaloy 2 is a cladding material of thickness $0.041 \mathrm{~cm}$ or $1.345 \times 10^{-3} \mathrm{ft}$.

He Layer

Cladding is $4.128 \times 10^{-3} \mathrm{~cm}=1.35 \times 10^{-4} \mathrm{ft}$, which is filled with Helium.

Thus, Outside diameter of fuel rod is $\mathbf{0 . 3 8 9} \mathbf{~ c m}$.

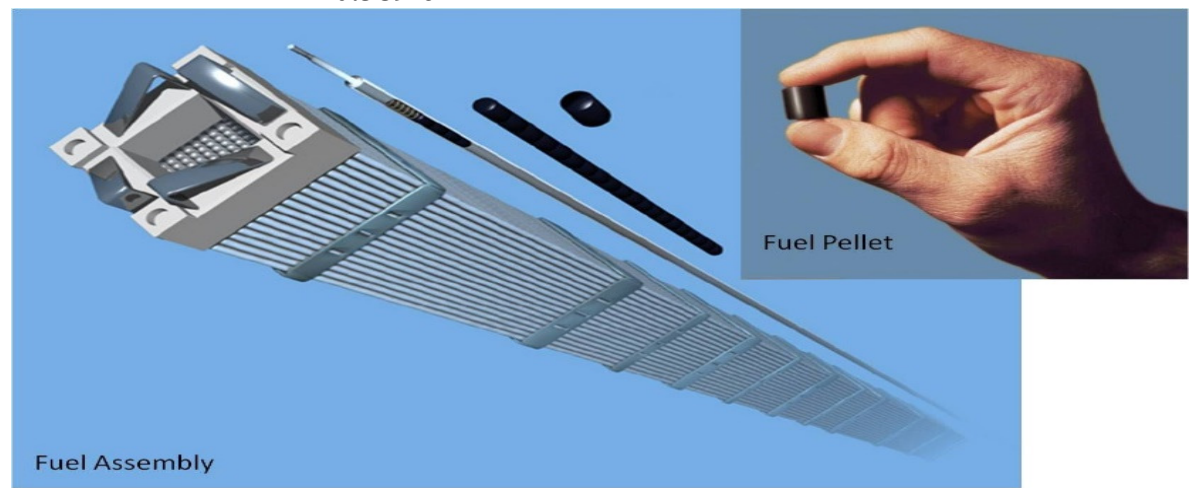

Figure 2: Fuel Assembly Design

Pitch is the distance between centers of two rods. Size of the assembly is the distance that is separated by the centers of two rods located at two apparent corners of the assembly. Assembly pitch is one line out the four that make the squared assembly that contains the rods inside it [9].

$$
\begin{aligned}
& \text { Volume of Moderator per Channel }=\mathrm{P}^{2} \times \mathrm{H}-\frac{\pi \times D^{2} * H}{4} \\
& \frac{0.77}{4 \times 225 \times 4 \mathrm{~m}}=\mathrm{P}^{2}-\frac{3.142}{4}\left(2 \times 0.389 \times 10^{-2}\right)^{2} \\
& \mathrm{P}=0.0161 \mathrm{~m} \\
& \mathbf{P}=\mathbf{1 . 6 1 \mathrm { cm }} \quad \begin{array}{c}
\text { Assembly pitch }=15(\text { dia of rod })+14(\text { pitch }) \\
=15(2 \times 0.389)+14(1.61)
\end{array}
\end{aligned}
$$


Assembly pitch $=34.21 \mathrm{~cm}$

2. Gross area $=($ assembly pitch $) 2$

Gross area $=1170.324 \mathrm{~cm}^{2}$

3. Fuel Rods Area per Assembly $=\mathrm{n} x \frac{\pi * \text { (dia of a single rod }) 2}{4}$

Fuel Rods Area per Assembly $=225 \mathrm{x} \frac{\pi x(2 \times 0.389) 2}{4}$

Fuel Rods Area per Assembly $=106.962 \mathbf{c m}^{2}$

4. Flow area per assembly $=$ Gross area - fuel rods area per assembly

Flow Area per assembly $=1063.362 \mathrm{~cm}^{2}$

1. Volumetric Coolant Flow Rate $=$ Primary Coolant Flow $\mathrm{x}$ Specific Volume

$$
\begin{aligned}
@ 322^{\circ} \mathrm{C} \text { Specific Volume } & =0.0015 \mathrm{~m}^{3} / \mathrm{kg} \\
\text { Primary Coolant Flow } & =\frac{q}{h 2-h 1} \\
& =\frac{40 \times 103}{93.401}
\end{aligned}
$$

Volumetric Coolant Flow Rate $=428.26 \times 0.0015$

Volumetric Coolant Flow Rate $=0.642 \mathrm{~m}^{3} / \mathrm{s}$

2. At operating conditions flow velocity is found to be $420.172 \mathbf{c m} / \mathbf{s}$

3. Total coolant flow area $=\frac{\text { volumetric coolant flow rate }}{\text { flow velocity }}=\frac{642390}{420.172}$

Total coolant flow area $=0.152 \mathbf{m}^{2}$

The arrangement of the Core is as follows:

1. Total Core Area $=$ No. of Assembly x $(\text { Pitch Assembly Area })^{2}$

$$
=4 \times(34.21)^{2}
$$

Acore $=4681.296 \mathrm{~cm}^{2}$

2. Equivalent dia. of core:

$$
\begin{gathered}
\text { Area }=\frac{\pi}{4} \times D_{\mathrm{e}}{ }^{2} \\
\mathbf{D}_{\mathrm{e}}=\mathbf{7 7 . 2 0 3} \mathrm{cm}
\end{gathered}
$$

Now,

3. $\mathrm{L} / \mathrm{D}$ ratio $=\mathbf{5 . 1 8}$

- $\quad$ Net Core Volume $=$ Total Core Area $\mathrm{x}$ Fuel Rod Length

$$
\begin{aligned}
& =4681.296 \times 400 \\
& =1.855 \times 10^{6} \mathrm{~cm}^{3}
\end{aligned}
$$

Net Core Volume $=\mathbf{1 8 7 2 . 5}$ liter

$$
\begin{aligned}
& \text { Net Heat Release/Unit Volume }=\frac{\text { Reactor Heat Power }}{\text { Net Core Volume }} \\
& =\frac{40 \times 103}{1.872 \times 106} \\
& =0.021 \mathrm{~kW} / \mathrm{cm}^{3} \\
& =21.36 \mathrm{KW} / \text { liter }
\end{aligned}
$$

\section{HEAT FLUX AND COOLANT FILM COEFFICIENT}

Using these calculations we shall be able to make thermal design i-e we shall be able to find the maximum temperature in fuel, the cladding inner and outer temperature and ensure the safe operation [10].

Max. Power density is assumed to be $\mathbf{3 5 8 . 2 7} \mathbf{W} / \mathbf{c m}$ length of fuel rod.

Thus, average power density is $=1 / 4(\max$. power density $)=\mathbf{8 9 . 5 6} \mathbf{w} / \mathbf{c m}$

Heat flux $=\frac{\text { Max.power density }}{\text { fuel rod perimeter }}=\frac{358.27}{3.142(0.778)}$

Heat flux $=146.582 \mathrm{~J} / \mathrm{cm}^{2}$.sec

Coolant film coefficient

Using Dittus Boelter equation

$$
\begin{gathered}
\mathrm{h}=8 \times 10^{-5}\left(1+10^{-2} \mathrm{~T}-10^{-5} \mathrm{~T}^{2}\right) \times \frac{v^{\wedge} 0.8}{D^{\wedge} 0.2} \\
; \mathrm{T}=322.5 \mathrm{C}=612.5 \mathrm{~F}
\end{gathered}
$$




$$
\begin{aligned}
& \mathrm{V}=49626.614 \mathrm{ft} / \mathrm{hr} \\
& \mathrm{D}=4 \times\left(\frac{\text { fuel assembly coolant flow area }}{\text { total fuel rod perimeter }}\right)=\frac{4 \times 1063.362}{3.142 \times 0.778 \times 225} \\
& \mathrm{D}=0.253 \mathrm{ft}
\end{aligned}
$$

Thus,

$$
\mathrm{h}=2.028 \mathrm{~J} / \mathrm{cm}^{2} . \mathrm{sec} \cdot \mathrm{C}=20280 \mathrm{~W} / \mathrm{m}^{2} . \mathrm{C}
$$

$1 \mathrm{~W} / \mathrm{m}^{2} . \mathrm{C}=0.176228 \mathrm{Btu} / \mathrm{hr}^{-\mathrm{ft}^{2}}{ }^{\circ} \mathrm{F}$

h $=3573.9 \mathrm{Btu} / \mathbf{h r} \mathbf{f t}^{2}{ }^{\circ} \mathrm{F}$

$\mathrm{q}=\frac{136.48 \times 10^{6}}{4 \times 225}=151.64 \times 10^{3} \mathrm{Btu} / \mathrm{hr}$

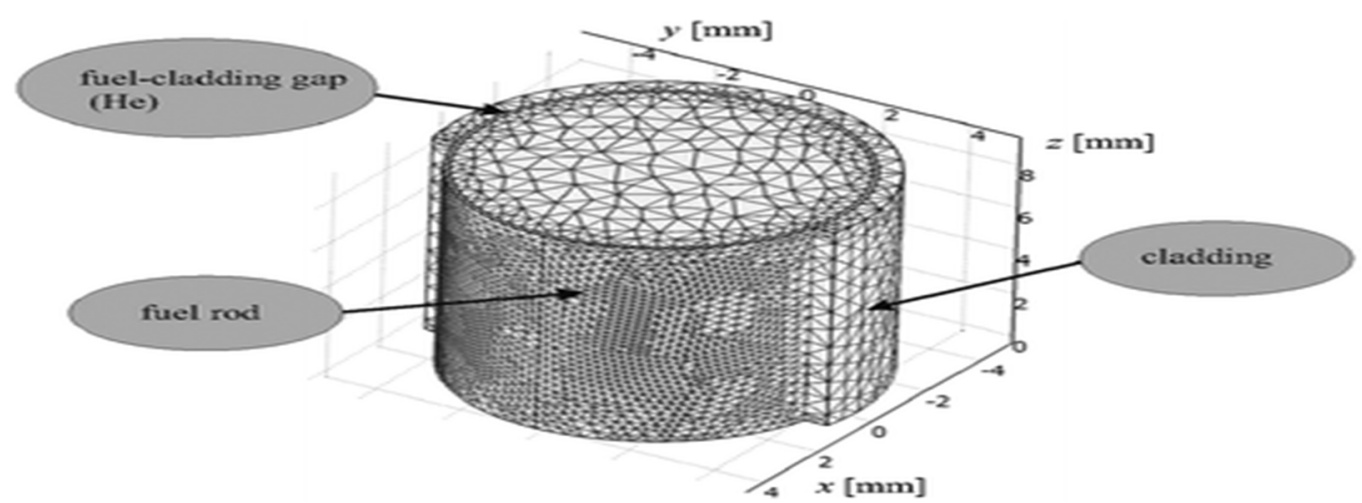

Figure 3: Thermal Design of fuel element

$$
\begin{aligned}
& \mathrm{q}=\frac{T m-T f}{\frac{R}{2 . K f \cdot A r}+\frac{c}{K c \cdot A m}+\frac{c_{H e}}{K_{H e} \cdot A_{H e}}+\frac{1}{h_{. A}+C+C_{H e}}} \\
& A_{r}=2 \pi R l=0.927 f t^{2} \\
& A_{m}=\frac{2 \pi c l}{\ln \left(\frac{R+c}{R}\right)}=0.984 f t^{2}
\end{aligned}
$$

$$
\begin{aligned}
& A_{H e}=2 \pi\left(\mathrm{R}+C_{H e}\right) \mathrm{L}=0.9412 f t^{2} \\
& A_{R+C}+C_{H e}=2 \pi\left(\mathrm{R}+\mathrm{C}+C_{H e}\right) \mathrm{L}=1.052 f t^{2}
\end{aligned}
$$

For Max. Midpoint Temperature

Applying all values to above Eq.:

$$
151,6410^{3}=\frac{T m-611.6}{0.927+0.984+0.9412+1.052}
$$

$\mathbf{T m}=1769.325^{\circ} \mathrm{F}=965.18^{\circ} \mathrm{C}$

For Inner Cladding Temperature

$$
\mathrm{q}=\frac{T m-T c 1}{\frac{R}{2 . K f \cdot A r}+\frac{c_{H e}}{K_{H e} \cdot A_{H e}}}
$$

$\mathrm{Tc}_{1}=\mathbf{6 7 7 . 8 2}^{\circ} \mathrm{F}=358.78^{\circ} \mathrm{C}$

\section{For Outer Cladding Temperature}

$$
\mathrm{q}=\frac{T m-T c 2}{\frac{R}{2 . K f \cdot A r}+\frac{c}{K c \cdot A m}+\frac{c_{H e}}{K_{H e} \cdot A_{H e}}}
$$$$
\mathrm{Tc}_{2}=651.92^{\circ} \mathrm{F}=344.4^{\circ} \mathrm{C}
$$

Since outer cladding temperature is less than the Melting point of Zircaloy 2 i-e $3310^{\circ} \mathrm{F}$ Therefore, Design is safe.

$$
\begin{aligned}
& q=h \times A \times\left(T_{s}-T_{a}\right) \\
& T a=T_{f 2}=321.89^{\circ} \mathrm{C} \text { i.e. coolant outlet temperature. }
\end{aligned}
$$

Setting the pressure at $16 \mathrm{MPa}$ to avoid boiling.

Since $\mathrm{T}_{\text {sat }} @ 16 \mathrm{MPa}$ is $347.44^{\circ} \mathrm{C}$,

which is greater than coolant temperature.

Hence the design is safe.

\section{CONCLUSIONS}

The design calculations were done for a nuclear reactor which is capable of producing fresh water amounting to 
2.6 MGPD which is equivalent to $114 \mathrm{~kg} / \mathrm{s}$. The design data collected and studied the using various literature sources gave good idea about the design of nuclear reactor operations, numerical analysis regarding nuclear heat generation and thermal design. The design calculations were performed in details to evolve the core neutronics and thermal design. For a $40 \mathrm{MW}$ (thermal) nuclear reactor. A matrix of $15 \times 15$ and fuel i.e. $3 \%$ enriched $\mathrm{UO}_{2}$ for fuel element was finalized. On the basis of numerical analysis using the similar conditions we have selected the parameters like $\mathrm{H}_{\mathrm{e}}$ layer thickness, cladding thickness of Zircalloy material, length of fuel rods and coolant bulk temperature. Executing the necessary calculations, we have finalized our nuclear reactor design which is used for heating purpose only. The main results are summarized as follows;

No. of Assemblies

$=4$

Amount of Fuel required $(\mathrm{kg}) \quad=\quad 1469.22$ (for cycle time of $2.5 \mathrm{yrs}$ )

Volume of coolant $\left(\mathrm{m}^{3}\right)$

$=0.77$

Heat release per unit volume $(\mathrm{KW} /$ liter $)=21.3$

Maximum mid-point temperature $\left({ }^{\circ} \mathrm{C}\right) \quad=\quad 965.18$

Coolant outlet temperature $\left({ }^{\circ} \mathrm{C}\right) \quad=\quad 321.89$

\section{REFERENCES}

[1] Al Wakil (1981) Nuclear Heat Transport, American Nuclear Society; First Edition, ISBN-13: 9780894480140

[2] Frank P. Incropera ,David P. DeWitt, Theodore L. Bergman, Adrienne S. Lavine (2006) Fundamentals of Heat and Mass Transfer, 6th Edition, , John Wiley \& Sons; 6th edition, ISBN-13: 978-0471457282

[3] H.T El-Dessouky and H.M Ettouney (2002) Fundamentals of Salt Water Desalination, Elsevier Science, ISBN: 9780444508102

[4] Heat Transfer: Fundamentals and Applications, 5th Edition, Yunus A. Cengel and Michael A. Boles, McGraw-Hill Education; 5 edition (April 4, 2014), ISBN-13: 978-0073398181

[5] J.R. Lamarsh and A.J. Baratta (2001) Introduction to Nuclear Engineering, Prentice Hall; 3rd edition (2001).

[6] R. M. Mayo (1998) Introduction to Nuclear Concepts for Engineers. American Nuclear Society, USA

[7] Yunus A. Cengel , Michael A.Boles. (2014). Thermodynamics: An Engineering Approach McGraw-Hill Education; 8 edition, ISBN-13: 978-0073398174

[8] S.E. Hedayat, A.A. Sary., (1977) Design of a small single-purpose nuclear desalination plant compatible with local resources in the Middle East", Desalination, Vol. 20, No. 1977, pp. 257-266.

[9] M. Methnani, R.Faibish., (2002) Status of design concept of nuclear desalination plants, IAEA-TECDOC1326.

[10] T. Konishi., (2000). "Introduction of Nuclear Desalination", Technical Report Series No.400 (IAEA) 